\title{
The Influence Of Asset Management Towards Optimization Of State As- sets In Working Units In The Denpasar High Court Region
}

\author{
Ni Luh Putu Sriastiti*, Ni Luh Anik Puspa Ningsih and Putu Ngurah Suyatna Yasa \\ Universitas Warmadewa, Denpasar Bali \\ srismiling75@yahoo.com
}

\begin{tabular}{|l|}
\hline \multicolumn{1}{|c|}{ Published: 30/03/2020 } \\
\hline How to cite (in APA style): \\
$\begin{array}{l}\text { Nurdiansyah, D, H., Ruchjana, E, T., Alfasari, M.(2020). The Influence Of Asset Management Towards Optimization Of } \\
\text { State Assets In Working Units In The Denpasar High Court Region. Jurnal Ekonomi dan Bisnis Jagaditha, 7(1), 24-38. } \\
\text { doi: https://doi.org/10.22225/jj.7.1.1414.24-38 }\end{array}$ \\
\hline
\end{tabular}

\begin{abstract}
This study aims to analyze the effect of asset management which includes planning needs, inventory, identification, legal audit, asset valuation, utilization and monitoring of asset optimization in employees in charge of assets in the Denpasar High Court Regional Work Unit. The data used in this study are primary data obtained through questionnaires. The population in this study were all employees in the field of assets in the Denpasar High Court Regional Work Unit, amounting to 73 people. Determination of the sample using the census technique in which all populations are sampled. Data analysis technique uses Partial Least Square with the help of PLS software program. Based on the results of hypothesis testing it can be stated that the Requirement Planning significantly positive effect on asset optimization. Inventory does not have a significant positive effect on asset optimization. The identification of positive effect is not significant on asset optimization. Legal audit does not have a significant positive effect on asset optimization. Asset valuation has a positive and significant effect on asset optimization. Utilization has a positive and not significant effect on asset optimization. And monitoring has a positive and not significant effect on asset optimization.
\end{abstract}

Keywords: Asset Management, Asset Optimization, Asset Valuation, Identification, Inventory, Legal Audit, Requirement Planning, Utilization, Monitoring

\section{INTRODUCTION}

Optimization of the management of state assets is regulated in Government Regulation of the Republic of Indonesia Number 27 of 2014 concerning Management of State / Regional Property (Anartany \& Suseno, 2018). The government regulation was followed up with the Circular of the Republic of Indonesia Supreme Court Administration Number 01 of 2017 concerning guidelines for the use and management of state property within the Supreme Court of the Republic of Indonesia and the judiciary below it. The scope of asset management itself includes, planning and budgeting needs, procurement, receipt, storage and distribution, use, administration, utilization, security and maintenance, assessment, deletion, transfer, guidance, supervision and control, financing, and claims for compensation.
Asset management in the Supreme Court of the Republic of Indonesia is identical to the management of State Property based on Government Regulation of the Republic of Indonesia Number 6 of 2006 concerning management of State / Regional Property. The scope of the management of

State Property as regulated by this Government Regulation must be in line with government accounting standards based on Government Regulation No. 71 of 2010 and generally accepted asset management principles (the best practices). According to (Hariyanto, Wijaya, \& Handono, 2017) there are several stages of asset management that can be done to improve asset optimization, namely planning needs, inventory, identification, legal audit, asset valuation, utilization and monitoring.

The Supreme Court of the Republic of Indonesia is a state judicial institution that has 
840 work units spread throughout Indonesia. The Denpasar High Court is the regional coordinator in charge of 20 work units consisting of 1 High Court work unit, 8 District Court work units, 9 Religious Court work units, 1 State Administrative Granting work unit and 1 Military Court work unit.

The phenomenon that exists in the area of the Denpasar High Court is that there are state houses whose conditions are slightly damaged to severely damage so that they require high maintenance costs. State-owned houses intended for judges or officials in work units whose condition is damaged are certainly not appropriate in terms of safety and comfort. There are still country houses that are not used by judges and court officials by preferring to rent a house or boarding house. The report on the condition of assets in the form of houses in the work unit of the Denpasar High Court in 2018 is presented in table 1 as follows.

Table 1

List of Service Houses in the District Court and Denpasar High Court Semester I 2018

\begin{tabular}{|c|c|c|c|c|c|c|}
\hline \multirow[b]{2}{*}{ No } & \multirow[b]{2}{*}{ Work unit } & \multirow{2}{*}{$\begin{array}{l}\text { Number of } \\
\text { Service } \\
\text { Houses }\end{array}$} & \multicolumn{3}{|c|}{ Condition of Home Service } & \multirow{2}{*}{$\begin{array}{c}\text { Not occu } \\
\text { pied }\end{array}$} \\
\hline & & & Well & $\begin{array}{c}\text { Damaged } \\
\text { lightly }\end{array}$ & $\begin{array}{l}\text { Severely } \\
\text { damaged }\end{array}$ & \\
\hline 1 & HC. Denpasar & 10 & 7 & 3 & 0 & 0 \\
\hline 2 & DC. Denpasar & 10 & 7 & 0 & 3 & 5 \\
\hline 3 & DC.Singaraja & 6 & 6 & 0 & 0 & 0 \\
\hline 4 & DC. Tabanan & 7 & 5 & 2 & 0 & 5 \\
\hline 5 & DC.Gianyar & 6 & 4 & 2 & 0 & 3 \\
\hline 6 & DC. Semarapura & 7 & 7 & 0 & 0 & 0 \\
\hline 7 & DC. Amlapura & 5 & 3 & 2 & 0 & 1 \\
\hline 8 & DC. Bangli & 6 & 3 & 3 & 0 & 0 \\
\hline \multirow[t]{2}{*}{9} & DC. Negara & 8 & 0 & 8 & 0 & 1 \\
\hline & Total & 55 & 42 & 20 & 3 & 15 \\
\hline
\end{tabular}

Source: State Supreme Court asset information system of the

Republic of Indonesia, 2018

Based on Table 1 that there are 3 heavily damaged assets owned by the Denpasar District Court, and there are 20 lightly damaged houses spread over the courts in the Denpasar High Court working unit. This shows that the management of assets in the Denpasar High Court area is not yet optimal. The government will be burdened from the maintenance budget if the use of state assets is less than optimal.

Another phenomenon related to the optimization of assets is the utilization of leases to third parties, namely the rental rates for official housing and canteen rental, which are still not in accordance with applicable regulations. There are still work units that have not yet charged official house rental rates according to the latest official housing house tariff calculations. Rent a canteen to a third party that has not yet received a fixing of the rental price from the KPKNL when the contract period has ended or that has never been submitted at all. Work units also feel reluctant to utilize vacant rooms that are still available for rent to third parties, of course, businesses that can support public services in the court such as photocopy services or opening credit outlets and so on.

The non-optimal increase in optimization of asset management is thought to be caused by the weak implementation of asset management which includes the planning of needs, inventory, identification, legal audit, asset valuation, utilization and monitoring activities in the Denpasar High Court working unit. The success or failure of the local government in achieving asset optimization is largely determined by asset management which includes the needs planning, inventory, identification, legal audit, asset valuation, utilization and monitoring (Hariyanto et al., 2017). The better asset management, the more optimal the optimization of assets.

One of the criteria that can be used as a reference to measure the success of asset management in improving asset optimization is that the Manager knows how the inventory, legal audit, asset valuation and monitoring of each asset owned / controlled (Atikoh, Febrian, \& Hendrawan, 2017). However, according to (Antoh, 2017) who conducted research on the Paniai district government found that asset management which includes inventory and valuation of assets has no effect on asset optimization. Based on the phenomenon and inconsistent research results, this is the author's research to conduct research on the effect of asset management on the optimization of state assets in work units in the Denpasar High Court. 
Based on the description above, the aims of this study was to analyze the effect of asset management which includes planning needs, inventory, identification, legal audit, asset valuation, utilization and monitoring of asset optimization in employees in charge of assets in the Denpasar High Court Regional Work Unit.

\section{CONCEPT AND HYPOTHESIS}

\section{Asset Optimization}

Aliasuddin (2002) states that optimality is one of the businesses to be achieved by each business unit. There are two aspects of optimality, namely maximizing profits and minimizing expenditure. Maximum production does not guarantee maximum profit. For this reason, optimal production is better than maximum production because optimal production guarantees maximum profit. (Sutrisno, 2004) defines asset optimization as a work process in asset management that aims to optimize the physical, location, value, amount / volume, legal and economic potential of the asset, optimizing these assets in a short time will result in the use and utilization of assets that are effective and efficient.

Asset optimization according to Nugent (2010) is the relationship between service usefulness and profit benefits. According to (Siregar \& D, 2004) asset optimization is a work process in asset management that aims to optimize the physical, location, value, amount / volume, legal and economic potential of the asset. In this stage, the assets owned by the regional government are identified and classified as potential and nonpotential assets. The asset optimization variable in this study was developed from the research of (Atikoh et al., 2017) namely, (1) Optimization of assets has been carried out following the appointment. (2) Optimization of fixed assets is comprehensive. (3) Optimization of assets involves third parties (private) and the community (partnerships). (4) Optimization of assets provides added value to increase non-tax revenue. (5) Optimization of assets accommodates assets that need to be removed as a form of efficiency.

\section{Asset Management}

Asset management is the science and art to guide wealth management which includes the process of planning asset needs, obtaining assets, inventorying, conducting legal audits, valuing assets, operating, maintaining, renewing or eliminating to transfer assets effectively and efficiently (Sugiama, 2013).
According to (Siregar \& D, 2004) asset management is one of the professions or expertise that has not been fully developed and popular in the government environment or in work units or agencies. Surminah (2008) states that asset management is a management system or a functional unit that functions / has the duty to operate a set of resources (human resources, money, machines, goods, time) and a set of instruments (methods, standards / criteria) to achieve a goal.

According to Brinkman (1999), Asset management is a process for managing demand and guiding the acquisition, use and disposal of assets to exploit the potential delivery of their services, and manage risks and costs throughout their lives. According to Hastings (2010), asset management is a series of activities related to (1) identifying what assets need, (2) identifying funding requirements, (3) obtaining assets, (4) providing logistical and maintenance support systems for assets, ( 5) delete or renew assets so that they can effectively and efficiently meet their objectives. Asset management can be divided into seven stages of work, namely planning needs, inventory, identification, legal audit, asset valuation, utilization, and monitoring (Hariyanto et al., 2017)

\section{Requirement Planning}

In Government Regulation Number 27 of 2014 concerning Management of State/ Regional Properties, Requirement Planning is the activity of formulating details of the needs of State/ Regional Properties to connect past procurement of goods with the current situation as a basis for future action. It can be interpreted that the needs plan is formulated from what items are needed to support the implementation of the duties and functions of the Ministry/ Institution/ Regional/ Institution reduced by what items are already available and ready to use.

(Tukunang, 2016) mentions that the planning of needs aims to make a match between the asset needs of an entity and the strategy of providing entity services that will produce assets with the required capacity and performance. Asset needs planning also gives direction to specific actions such as buying new assets as needed, selling excess assets, and operating and maintaining assets effectively. Research conducted by Oktaviana (2010) formulated indicators of needs planning, among others, (1) Requirement Planningaccording to asset conditions (2) Standardization of work facilities and 
infrastructure. (3) Goods that are still operational feasible have been proposed to be eliminated or rejuvenated. (4) Guided by the list of asset needs.

\section{Inventory}

Minister of Home Affairs Regulation No. 17 of 2007 Article 1 paragraph 31 concerning the Technical Guidelines for Regional Goods Management states that inventory variation is an activity or action to carry out the calculation, administration, organization, regulation, data recording and reporting of goods in use. Inventory goods are all goods owned / controlled by local governments that have been used for more than one year and are recorded and registered in the inventory book. According to (Siregar \& D, 2004), inventory consists of two aspects, namely physical and legal / legal variations. Physical aspects consist of form, location, volume / amount, type, address and others. Juridical aspects are the status of mastery, legal problems that are owned, the deadline of mastery and others.

Based on Regulation of the Minister of Home Affairs Number 19 of 2016, inventorying is an activity of carrying out arrangements, recording assets, compiling a list of relevant assets into a regular inventory of assets, and managing assets according to existing provisions. Research conducted by (Atikoh et al., 2017) formulate inventory indicators namely (1) Guided by applicable regulations. (2) The process of collecting data, recording and reporting activities. (3) Refers to the data, location, and condition of the actual assets. (4) Database of assets according to conditions. (5) There is an asset census.

\section{Identification}

Identification is an activity that seeks, finds, collects, researches, registers, records data and information from needs in the field. In intensity, the needs can be categorized into two types namely felt needs that are urgent and unexpected needs that are not urgent. Identification is an activity or action to classify and define state assets properly and provide a code so that it can be known with certainty the function and use as well as the location and area of goods of these assets (Widayanti, 2010).

\section{Legal Audit}

(Siregar \& D, 2004) states that legal audit is an Asset Management scope of work in the form of an inventory of the status of asset control, systems and procedures for controlling or transferring assets, identifying and finding solutions to legal problems, and strategies to solve various legal problems related to control or transfer of assets. Legal problems are often encountered, among others, weak status of ownership rights, assets controlled by other parties, transfer of assets that are not monitored and others. Minister of Home Affairs Regulation No. 17 of 2007 article 45 explained that the legal audit is also a security measure or control, control in an effort to deal with regional physical goods, administration and legal actions. Administrative safeguards can be carried out by means of completing proof of ownership such as Building Permit (IMB), minutes of handover, agreement letter, deed of sale, and other supporting documents.

(Atikoh et al., 2017) formulating legal audit indicators including, (1) The process of legal asset clarity has been carried out under applicable regulations. (2) All assets have a clear legal status. (3) Fixed assets in the form of land have been certified in the name of the Government of the Republic of Indonesia. (4) Fixed assets in the form of buildings have been completed with proof of ownership on behalf of the Government of the Republic of Indonesia. (5) Security of fixed assets includes administrative security, physical security and legal protection. (6) Legal audit is intended to prevent the loss of fixed assets. (7) A wellconducted legal audit process can contribute to optimizing assets.

\section{Asset Valuation}

Asset valuation is a work process for evaluating assets that are controlled, knowing the value of regional assets, and determining prices for the assets to be sold. (Siregar \& D, 2004). Usually the valuation of these assets is carried out by an independent valuation consultant. Based on the Minister of Domestic Affairs Regulation No.17 of 2007 Article 1 paragraph 32 concerning

Technical Guidelines for the Management of Regional Goods, the valuation of regional property is carried out in the framework of preparing regional government balance sheets, the utilization and transfer of regional property goods. The valuation of goods (assets) is guided by the Regional Government Accounting Standards, the activity of valuing regional property must be supported by accurate data on all ownership of regional assets (assets) recorded in the inventory list of assets belonging to the region (assets). (Atikoh et al., 2017) formulate asset valuation indicators, among others, (1) The valuation process has been carried out based on 
applicable regulations. (2) Determination of asseT Statisticss is guided by Government Accounting Standards. (3) Asset valuation is carried out by a team of related institutions and involves government (DJKN) or independent (certified) assessors. (4) Asset valuation provides information about the value of assets for future use of assets. (5) Asset valuation with the lowest estimate using NJOP.

\section{Utilization}

Utilization is one form of optimization of asset management carried out by the government. Utilization must be carried out in accordance with its designation as well as use (Ayomi \& Suparmi, 2014). Utilization must not be out of the designated designation (must be in accordance with the established rules). Based on the Regulation of the Minister of Finance No. 96 / PMK.06 / 2007, utilization can be made in the form of leases, loans, use of cooperation, utilization and build-up or wakeup purposes by not changing ownership status.

Oktaviana (2010) formulated utilization indicators including, (1) There are still assets that have not been managed and utilized properly. (2) Utilization of assets which are not yet optimal can be managed by the government bureaucrat apparatus in order to become an optimal profit center. (3) utilization of assets is managed by third parties in the form of Built Transfer and Operate, Built Operate and Transfer, Joint ventures, and other forms of cooperation

\section{Monitoring}

(Siregar \& D, 2004) states that monitoring is an issue that is often blasphemous to local governments today. One effective means of increasing monitoring is the development of an Asset Management Information System (SIMA). Through SIMA, work transparency in asset management is guaranteed without the need for fears of weak supervision and control. With SIMA, every treatment for one monitored asset is clear, starting from the scope of handling to who is responsible for handling it. This is expected to minimize KKN (Corruption, Collusion and Nepotism) within the local government body.

Based on Minister of Home Affairs Regulation No. 19 of 2016 Article 481 and Article 482 (renewal of Regulation of the Minister of Home Affairs No. 17 of 2007) concerning Technical Guidelines for the Management of Regional Goods. Asset monitoring is an effort or activity to guarantee, direct, know and assess the actual reality regarding the implementation of tasks and / or activities, whether carried out in accordance with applicable laws and regulations. (Atikoh et al., 2017) formulating utilization indicators including, (1) Monitoring is carried out properly on a regular basis. (2) Monitoring uses the Management Information System and Accounting for State Property (SIMAK ASET STOP). (3) Professionalism of human resources. (4) Functional supervisors carry out follow-up audits of monitoring results. (5) Information technology and completeness of infrastructure facilities support Ordinal fixed asset management activities.

\section{Asset Planning and Asset Optimization}

The results of research conducted by (Tukunang, 2016) which conducted research on the SKPD of the Regional Financial and Asset Management Revenue Service (PPKAD) in Siau Tagulandang and Biaro Islands Districts, found the results that Requirement Planning had a significant effect on asset optimization. Requirement Planning are prepared by taking into account the various needs of each SKPD and the availability of property or assets that already exist. Requirement Planninginclude planning procurement, planning maintenance, planning utilization, planning the alienation, and planning the elimination of assets or property belonging to the area.

(Hariyanto et al., 2017) examines the effect of asset management on asset optimization on DJKN operational office staff and officials consisting of DJKN Regional Offices and KPKNL in Indonesia. It was found that the Requirement Planning have a significant positive effect on asset optimization. Government needs planning must really pay attention to economic aspects, efficiency, and effectiveness (value for money) for productive sectors and produce a multiplier effect for the economy (Wibowo, 2013).

H1: Requirement Planning a significant positive effect on asset optimization.

\section{Inventory and Asset Optimization}

The results of research conducted by (Montayop, Ratang, \& Kambu, 2016), (Ayomi \& Suparmi, 2014), (Pauweni, Karamoy, \& Gamaliel, 2017)), (Nasution, Nasution, \& Absah, 2015), Demetow et al. (2017) and (Octanary \& Ridwan., 2018), (Jamaludin, 2017) shows that inventory has a positive and significant effect on asset optimization. With the implementation of the inventory includes data collection, coding / labeling, grouping, and opening / good administration it will provide predictions of a good level of asset 
optimization as well. Inventory increases or improves the level of optimization of management and utilization of fixed assets will also be better or that the drive to increase the value of inventory will also increase the level of optimization of management and utilization of fixed assets.

Whereas the research conducted by Pratama and Pangayo (2016), (Antoh, 2017), Anartary and Suseno (2018), (Umbora, Falah, \& Pangayow, 2018) showed that the inventory results had no effect on asset optimization. The application of an inventory does not guarantee the optimization of asset management. The impeded inventory is due to the lack of competent and knowledgeable employees about asset management and accounting education background. During this time in asset management, the government set policies without looking at the actual condition of the assets. This causes asset management to not be optimal because not all regulations issued are in accordance with field conditions.

$\mathrm{H} 2$ : Inventory has a significant positive effect on asset optimization.

\section{Identification and Asset Optimization}

Research conducted by Widayanti (2010), (Nasution et al., 2015), (Hariyanto et al., 2017) examining the effect of asset management on asset optimization found that identification has a positive and significant effect on asset optimization. Identification is very closely related and usually goes hand in hand with the inventory process carried out by the satker, every time there is a procurement of new assets should be identified with the aim to classify and give an asset identity code, so that in general has a significant positive effect on improving asset optimization.

While research conducted by (Hidayati, Wajdi, \& A.A Setyawan, 2016) and (Umbora et al., 2018) conducted research on the effect of asset management on asset optimization, it was found that identification had no effect on asset optimization. The results also indicate that identification has not improved the optimization of asset utilization, this is due to differences in the item code of the goods concerned with those listed in the Room Item List, the number of items that do not match those listed on the Room Item List. Difficult to process the removal of goods so that goods whose condition is damaged have been moved from the room, even though they are still listed on the Room Item List so the identification process cannot be carried out properly.

H3 : Identification has a significant positive effect on asset optimization.

\section{Legal Audit and Asset Optimization}

The results of the study of (Montayop et al., 2016), Fadli (2015), Septiana (2015), Pratama and Pangayo (2016), (Octanary \& Ridwan., 2018), Anartary and Suseno (2018), (Atikoh et al., 2017) shows that legal audit affects the optimization of assets. The importance of the legal status of fixed assets determines the pace of the development process because all construction requires complete documents such as land certificates. Clarity on the status of fixed assets will also avoid the bias of ownership and utilization of fixed assets and to avoid disputes.

Meanwhile, (Jamaludin, 2017), (Pauweni et al., 2017) and Demetow et al. (2017), (Umbora et al., 2018) shows the results of legal audits have no effect on asset optimization, legal audits bring regional governments to be more alert and more sensitive to complete documents and proof of ownership of regional government assets. The local government certainly wants the assets used and utilized by the regional government to be at a safe point and does not provide opportunities for other parties who want to control these assets in an irresponsible way. The local government certainly wants a change for the better the validity of asset ownership documents, and it is expected that the number of assets with complete ownership documents will increase every year and the problem of asset disputes due to smaller ownership documents with other parties.

H4: Legal audit has a significant positive effect on asset optimization.

\section{Asset Valuation and Asset Optimization}

(Asman \& Akram, 2016), (Ayomi \& Suparmi, 2014), Nasution et al., (2015), (Atikoh et al., 2017), (Hariyanto et al., 2017), (Octanary \& Ridwan., 2018), (Umbora et al., 2018), (Martini \& Midarsih, 2019) found that asset valuation results influence asset optimization, asset valuation must refer to Government accounting Standards (SAP) where in SAP it is explained that each fixed asset in a government must be depreciated or depreciated in order to aim to optimize assets. A good valuation process will be able to increase the utilization and optimization of state assets. In addition, a good assessment process will also increase accountability.

Meanwhile Pratama and Pangayo (2016), (Antoh, 2017) and (Hidayati et al., 2016) examined the effect of valuation on asset 
optimization, the results of the analysis showed that asset valuation had a significant negative effect on asset optimization, which means that respondents' perceptions of asset valuation had not contributed or increased significantly. positive on optimizing regional assets. This is due to the absence of good asset management.

H5: Valuation has a significant positive effect on asset optimization

\section{Utilization and Asset Optimization}

Research of (Ayomi \& Suparmi, 2014) aims to analyze the effect of asset management on the optimization of fixed assets (land and buildings) of Local Governments in Manokwari Regency. The analysis shows that the utilization of assets influences the optimization of assets. Utilization of assets carried out by not changing the status of assets. One of the benefits derived from utilization is that the costs of maintaining and securing assets are borne by the utilization partners, which is a saving to the APBN. The results obtained from the utilization of assets are state revenue, so they must be deposited into the state general cash account.

Meanwhile, for the results of the research (Hariyanto et al., 2017) which examines the effect of asset management on asset optimization on DJKN officials and office operational staff in Indonesia. It was found that the utilization of assets had a positive and significant effect on asset optimization. The better the leader in asset utilization, the better the asset optimization.

H6: Utilization has a significant positive effect on asset optimization

\section{Monitoring and Asset Optimization}

(Tukunang, 2016), Demetow (2017), (Tafazzoli, 2017), (Hariyanto et al., 2017),

(Atikoh et al., 2017), (Antoh, 2017), (Maulidiah, 2017) found the results of monitoring affect the optimization of assets, if the implementation of asset monitoring increases, the average optimization of assets will rise. Monitoring is very important to ensure the smooth running of optimizing local government assets. The monitoring process is needed to avoid various forms of irregularities in the planning process and in the process of managing assets / goods belonging to local governments, namely the Asset Management Information System, with this Asset Management Information System will be able to ensure the implementation of the principle of transparency in the management of assets / goods belonging to local governments, because all aspects of the management of assets / goods belonging to local governments will be accommodated in a new system that can be clearly monitored by all components of society and stakeholders.

Meanwhile, for the results of the study (Asman \& Akram, 2016) shows that there is a positive and insignificant influence between monitoring and asset optimization in the Sumbawa Regency Government. The weak influence of monitoring on the optimization of assets in the Sumbawa Regency

Government is indicated because the head of the SKPD is still less than optimal in monitoring the management, use or security of regional property in his control. In addition, the role of the inspectorate as an internal auditor in the oversight process and assesses the accounting policies implemented by the SKPD are less than optimal

H7: Monitoring has a significant positive effect on asset optimization

\section{Conceptual Framework}

Asset optimization is a work process in asset management that aims to optimize the physical potential, location, value, amount / volume, legal and economic assets of the asset (Sutrisno, 2004). There is potential for state revenue that can be optimized from managing state assets, namely by utilizing state assets that can provide money to the state. Optimization does not have to be in the form of state revenue but can be in the form of maximizing the use of assets.

The success or failure of the local government in achieving asset optimization is largely determined by asset management which includes the needs planning, inventory, identification, legal audit, asset valuation, utilization and monitoring (Hariyanto et al., 2017). One of the criteria that can be used as a reference to measure the success of asset management in improving the optimization of assets is the Manager knows how the inventory, legal audit, asset valuation and monitoring of each asset owned / controlled (Atikoh et al., 2017). However, according to

(Antoh, 2017) who conducted research on the Paniai district government found that asset management which includes inventory and valuation of assets has no effect on asset optimization.

The design of this study uses quantitative methods, to explain the effect of planning needs, inventory, identification, legal audit, 
valuation, utilization and monitoring of asset optimization. This research was conducted at the Work Unit in the Denpasar High Court
Area. Then the conceptual framework can be described as shown in figure. 1

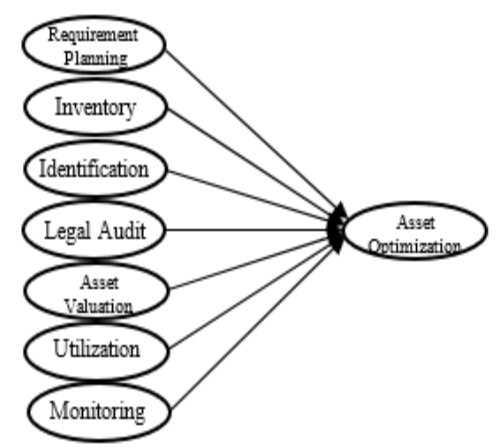

Figure 1

Framework

\section{METHODS}

This study uses a quantitative type of survey method. Quantitative research is defined as an investigation of social or humanitarian problems by examining theories that are built on a number of variables, measured by numbers, and analyzed by statistical procedures, to ensure the truth of the predictive generalizations of the theory (Creswell, 2003). This research is also a causal study that examines the influence between variables. The object of this research is all employees in charge of assets in the work units in the Denpasar High Court. This study uses PLS to analyze the relationships between variables.

Data collection using research methods and instruments consisting of observations, interviews, literature studies, questionnaires (questionnaire). The population in this study were 73 employees in charge of asset management in each work unit in the Denpasar High Court. The sampling technique in this study is to use a census technique in which all populations are sampled presented in the following table 2 .

Table 2

Number of Populations and Research Samples

\begin{tabular}{ccc}
\hline No & Name of Work Unit & $\begin{array}{c}\text { Number of } \\
\text { Asset Field } \\
\text { Workers }\end{array}$ \\
\hline 1 & Denpasar High Court & 5 \\
2 & Denpasar District Court & 5 \\
3 & Tabanan District Court & 4 \\
4 & Gianyar District Court & 4 \\
5 & Bangli District Court & 4 \\
6 & Semarapura District Court & 4 \\
7 & Amlapura District Court & 4 \\
8 & Singaraja District Court & 4 \\
9 & Negara District Court & 4 \\
10 & Denpasar Religious Court & 3 \\
11 & Badung Religious Court & 3 \\
12 & Tabanan Religious Court & 3 \\
13 & Gianyar Religious Court & 3 \\
14 & Semarapura Religious Court & 3 \\
15 & Amlapura Religious Court & 3 \\
16 & Singaraja Religious Court & 3 \\
17 & Negara Religious Court & 3 \\
18 & Bangli Religious Court & 3 \\
19 & Military Court & 4 \\
20 & Administrative Court & 4 \\
& Total & 73 \\
\hline
\end{tabular}




\section{RESEARCH FINDING}

Table 3.

Statistical Test Results

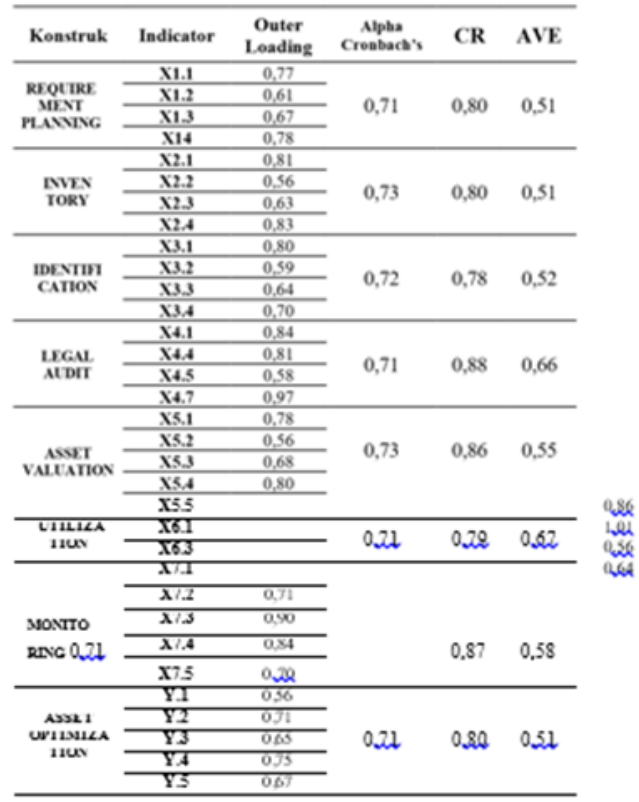

Convergent validity is a criterion in measuring the validity of indicators that are reflexive. This evaluation is done through an examination of the outer loading coefficient of each indicator of its latent variable. An indicator is said to be valid, if the outer loading coefficient is between $0.60-0.70$, but for analyzes whose theories are unclear, an outer loading of 0.50 is recommended (Lathan and Ghozali, 2012: 78). The calculation results regarding the outer loading value in Table 3 show that all indicators have met the valid requirements based on the convergent validity criteria, namely the outer loading value $>0.50$ and statistically significant.
The reliability test results of the research instruments in Table 3 show that the Alpha Cronbach value in each construct was $>0.60$ which means that the reliability of all research variables was categorized as good and accepted (Nunnaly criteria, 1969). For the composite reliability value of each construct in Table 3 has shown a value greater than 0.70 so that it meets the reliable requirements based on composite reliability criteria. While the AVE index value of each construct in Table 3 has shown to be greater than 0.50 , so it is declared valid based on discriminant validity criteria. These results can be seen in Fig 2.

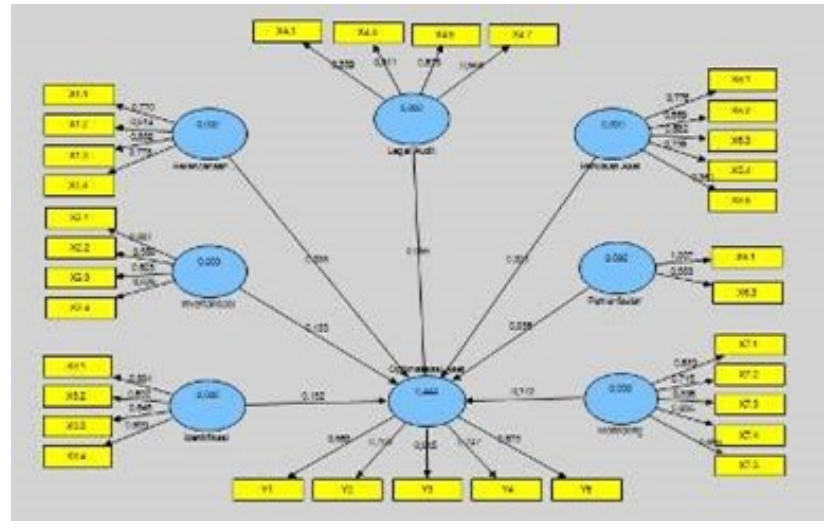

Figure. 2

Outer Loading and Path Analysis Estimated Results 
High Court Region

\begin{tabular}{cc} 
Table 4 & \\
Evaluation of the Inner Structural Model & R Square \\
\hline Konstruk & 0,44 \\
Asset Optimization &
\end{tabular}

In Table 4, the R2 value of the asset optimization construct is shown with a yield of 0.44 , then the model includes moderate to strong model criteria based on Chin criteria (Lathan and Ghozali, 2012: 85). This means that other constructs such as needs planning, inventory, identification, legal audit, asset valuation, utilization and monitoring are able to explain the construct optimization of assets by 44 percent, while the remaining 56 percent is explained by other constructs outside the analyzed model.

Q-Square Predictive Relevance (Q2) is a

measure of how well the observations made give results to the research model. The criteria for strength and weakness of the model measured based on Q-Square Predictive Relevance (Q2) according to Lathan and Ghozali (2012: 85) are 0.35 (strong model), 0.15 (moderate model), and 0.02 (weak model). The value of Q-Square shown in Table 4 is $=1-(1-\mathrm{R} 21)=1-(1-0.44)=1-0.56=$ 0.44 , based on this value, the estimated model is included in the strong criteria based on Lathan and Ghozali (2012: 85), meaning that $44 \%$ of endogenous veriable can be predicted by exogenous variables.

Table 5

Evaluation of Goodness Of Fit

\begin{tabular}{ccc}
\hline Konstruk & $\begin{array}{c}\text { R Square Communali- } \\
\text { ty }\end{array}$ \\
\hline Identification & & 0,96 \\
Inventory & & 0,92 \\
Legal Audit & & 0,93 \\
Monitoring & & 0,93 \\
Asset Optimization & 0,44 & 0,95 \\
Utilization & & 0,85 \\
Asset Valuation & & 0,91 \\
Requirement Planning & & 0,95 \\
Average & 0,44 & 0,92
\end{tabular}

Goodness of Fit (GoF) is a measurement of the overall accuracy of the model, because it is considered a single measurement from the measurement of the outer model and measurement of the inner model. Based on Lathan and Ghozali (2012: 88), the criteria of strength and weakness of the model based on the measurement of Goodness of Fit (GoF) are 0.36 (GoF large), 0.25 (GoF medium), and

0.10 (GoF small). In Table 5 the GoF value shows an average value of $\mathrm{R} 2$ of 0.44 while an average of Communality of 0.92 , then the GoF value of $\sqrt{ }$ AR2 $*$ A.Com $=\sqrt{ } 0.44 * 0.92=\sqrt{ }$ $0.40=0.64$ This means that the global model is a large predictive based on Lathan and Ghozali (2012: 88).

\section{DISCUSSION}

Table 6

Path Analysis and Testing Statistics

\begin{tabular}{|c|c|c|c|c|c|c|c|}
\hline \multicolumn{4}{|c|}{ Original Konstruk Sample (O) } & \multicolumn{4}{|c|}{$\begin{array}{l}\text { Sample Standard Standard Mean Deviation Error (M) T Statistics }(\mid \mathbf{O} / \\
\text { (STDEV) (STERR) } \\
\text { STERR } \mid)\end{array}$} \\
\hline \multicolumn{2}{|c|}{ Identification -> Asset } & \multicolumn{2}{|c|}{ 0,132 Optimization } & 0,121 & 0,103 & 0,103 & 1,281 \\
\hline Inventory -> & Asset & \multicolumn{2}{|c|}{ 0,133 Optimization } & 0,138 & 0,100 & 0,100 & 1,332 \\
\hline Legal Audit -> & Asset & \multicolumn{2}{|c|}{0,056 Optimization } & 0,078 & 0,092 & 0,092 & 0,609 \\
\hline Monitoring -> & Asset & \multicolumn{2}{|c|}{ 0,172 Optimization } & 0,174 & 0,122 & 0,122 & 1,414 \\
\hline Utilization -> & Asset & \multicolumn{2}{|c|}{ 0,036 Optimization } & 0,054 & 0,105 & 0,105 & 0,346 \\
\hline \multicolumn{4}{|c|}{ Asset Valuation -> 0,321 Asset Optimization } & 0,309 & 0,082 & 0,082 & 3,900 \\
\hline \multicolumn{2}{|c|}{$\begin{array}{l}\text { Requirement Planning -> } \\
\text { mization }\end{array}$} & Asset & 0,338 Opti- & 0,326 & 0,079 & 0,079 & 4,299 \\
\hline
\end{tabular}




\section{Influence of Requirement Planning on Asset Optimization}

Requirement Planning a positive effect of 0.34 on asset optimization, and the relationship is significant at the 0.05 level with a $\mathrm{T}$ Statistics of 4.29 greater than the Ttable value of 1.96. The results of the analysis show that with good asset planning will provide predictions of good asset optimization as well. The activity Requirement Planningby taking into account the suitability of the assets needed by the agency, the number of employees, maintenance costs, standardization of work facilities and infrastructure and based on a better list of asset requirements will support the improvement of asset optimization in the Work Unit in the Denpasar High Court Area.

The asset management information system implemented in the Work Unit in the Denpasar High Court Area is in accordance with the SBSK and the concept of planning for asset optimization, which the system will reject if there is an inappropriate planning of asset requirements. However, the satker users of state assets are not required to plan together with the KPKNL. The KPKNL is only involved in the planning process if the satker submits assistance. Asset Requirement Planningto be discussed intensively when the planning proposal has reached the vertical satker unit in the center with DJKN who is also the KPKNL vertical unit at the center. For this reason, the asset manager must have a database of assets that is reliable and in accordance with the latest conditions. The database supports basic knowledge of assets that must be owned by asset managers in which asset managers (DJKN to KPKNL) must know what assets they have and where they are (Hastings, 2010). Government spending must really pay attention to economic aspects, efficiency, and effectiveness (value for money) for productive sectors and produce a multiplier effect for the economy (Wibowo, 2013).

The results of this study are in line with the results of previous studies conducted by (Tukunang, 2016) and (Hariyanto et al., 2017) who conducted research on the SKPD of the Regional Financial and Asset Management Revenue Service (PPKAD) in Siau Islands, Tagulandang and Biaro Districts, found the results that Requirement Planning had a significant effect on asset optimization. Requirement Planning are prepared by taking into account the various needs of each SKPD and the availability of property or assets that already exist. Requirement Planninginclude planning procurement, planning maintenance, planning utilization, planning the alienation, and planning the elimination of assets or property belonging to the area.

\section{Influence of Inventory on Asset Optimization}

Inventory has a positive effect on optimization of 0.13 , but the relationship is not significant at the 0.05 level with a $\mathrm{T}$ Statistics of 1.33. Smaller than 1.96. The application of inventory does not guarantee the optimization of asset management in the Denpasar High Court Regional Work Unit. The implementation of the inventory in the Denpasar High Court Regional Work Unit is still not orderly, especially in collecting data on the actual condition of the goods. The implementation of the inventory is based on regulations that apply at least every 5 years but the actual inventory is carried out more than five years. This causes asset management to not be optimal because not all regulations issued are in accordance with field conditions.

(Hariyanto et al., 2017) explain that asset management is broader than the administration of assets where the majority of activities are just recording. For this reason, the Work Unit in the Denpasar High Court Area should have an inventory of the assets under their control. Inventory will greatly support the next asset management activities, so that the optimization of assets will be easily achieved because the potential of each asset is easily known. The existence of an inventory requirement, in addition to supporting the reliability of the database on the power side of users of goods will also strengthen the database in the manager of goods in this case DJKN through reconciliation.

The results of this study are in line with the results of previous studies conducted by (Umbora et al., 2018) showing the results that the inventory does not affect the optimization of assets, the possibility of an inventory has no effect caused by an inventory that is less orderly and not well managed so that it cannot show all regional property wealth that is material, both moving and not moving. The hampered inventory is also due to the lack of competent and knowledgeable employees about asset management and accounting education background. Other related studies that show inventory results have a positive and not significant effect on asset optimization delivered by Pratama and Pangayo (2016), (Antoh, 2017), Anartary and Suseno (2018).

The results of this study contradict the 
results of previous studies conducted by (Asman \& Akram, 2016). (2016), (Jamaludin, 2017), (Pauweni et al., 2017), (Ayomi \& Suparmi, 2014) and (Montayop et al., 2016) shows the results that inventory has a positive and significant effect on asset optimization. The better or better the inventory, the better the level of optimization of management and utilization of fixed assets.

\section{Influence of Identification on Asset Optimization}

Identification has a positive effect of 0.13 on asset optimization, but the relationship is not significant at the 0.05 level because the $\mathrm{T}$ Statistic value is smaller than 1.96 which is equal to 1.28 . This means that the application of identification does not guarantee the optimization of asset management in the Work Unit in the Denpasar High Court Area. During this time the ability of employees of the Work Unit in the Denpasar High Court Area in the implementation of identification has not been maximized, this is due to the absence of SOP (Standard Operational Procedure) established by the Supreme Administrative Court of the Republic of Indonesia which regulates the implementation of procurement, storage and write off assets.

Asset management process in terms of increasing asset optimization in the Work Unit in the Denpasar High Court Area has guided and understood the policy of managing state assets, standardization of work facilities and infrastructure, standardization of unit prices, but has not been able to improve asset optimization due to the absence of Operational Standards Procedure which regulates regulations regarding the implementation of procurement, storage, distribution and use of the elimination and transfer of state-owned assets. During this time in asset management, the Work Unit in the Denpasar High Court Area is still less than optimal in defining each asset clearly about its use and designation. This causes asset management to not be optimal because not all regulations issued are in accordance with field conditions.

The results of this study are in line with the results of research conducted by (Umbora et al., 2018)(Hidayati et al., 2016) that identification has no effect on asset optimization. These results also indicate that identification has not improved optimization, this is due to differences in the item code of the goods concerned with those listed in the Room Item List, the number of items that do not match those listed on the Room Item List.

The results of this study contradict the results of previous studies conducted by (Hariyanto et al., 2017), (Nasution et al., 2015) and Widayanti (2010) examined the effect of identification on asset optimization, the results of identification have an effect on the optimization of assets. The better the identification will improve the optimization of assets, and identification is needed when procurement of new assets.

\section{Influence of Legal Audit Asset Optimization}

Legal audit has a positive value of 0.06 towards asset optimization, and the relationship is not significant at the 0.05 level with a $\mathrm{T}$ Statistics of 0.61 smaller than the $\mathrm{T}$ table value of 1.96. The implementation of legal audit does not guarantee the optimization of asset management in the Work Unit in the Denpasar High Court Area. This is due to the lack of understanding of the parties related to state assets regarding the importance of status and proof of ownership of these assets. With status and strong evidence of ownership of state assets, it should be able to optimize the use and utilization of these assets. The Work Unit in the Denpasar High Court Area is still not maximized in conducting a legal audit of existing assets.

Legal audit problems that are often encountered include among others there are still several land and building assets belonging to the Work Unit in the Denpasar High Court Area whose ownership status has yet to be determined, in other words not having PSP (Determination of Owner Status). PSP is a mandatory requirement for asset removal or asset rejuvenation. In addition, the Work Unit in the Denpasar High Court Area is also trying to make a building permit as a sign of ownership of assets in the form of a legal building on behalf of the Government of the Republic of Indonesia.

The Work Unit in the Denpasar High Court Area in an effort to optimize assets has so far been hampered in terms of the security of fixed assets (land and buildings) which are carried out including administrative protection, physical security, and legal protection. So that asset management in terms of the legal audit process does not contribute to optimizing assets.

The results of this study are in line with the results of previous studies conducted by Demetow et al. (2016), (Pauweni et al., 2017), (Jamaludin, 2017), and (Umbora et al., 2018) show that the results of legal audit have no 
effect on asset optimization, legal audits bring regional governments to be more alert and more sensitive to complete documents and proof of ownership of regional government assets. The local government certainly wants the assets used and utilized by the regional government to be at a safe point and does not provide opportunities for other parties who want to control these assets in an irresponsible way.

The results of this study contradict the results of research conducted by (Montayop et al., 2016), Fadli (2015), Septiana (2015), Pratama and Pangayo (2016), (Octanary \& Ridwan., 2018), Anartary and Suseno (2018), (Atikoh et al., 2017) found the results of the legal audit affect the optimization of assets, with the implementation of a good legal audit will provide predictions of a good asset optimization.

\section{Influence of Asset Valuation on Asset Optimization}

Asset valuation has a positive effect of 0.32 on asset optimization, and the relationship is significant at the 0.05 level with a $\mathrm{T}$ Statistics of 3.90 greater than the Ttable value of 1.96. This means that if the asset valuation increases or gets better, the level of asset optimization in the Work Unit in the Denpasar High Court Area will also be better The asset valuation process at the Work Unit in the Denpasar High Court Area has been carried out by a team of related institutions and involving government appraisers (DJKN) or independent (certified), i.e. KPKNL (Office of State Assets and Auction Services) in accordance with government regulations

In the case of carrying out asset valuation at the Work Unit in the Denpasar High Court, employees of the asset sector are entrusted with the authority of the user of the goods to fill in the forms related to the object concerned. So the asset valuation function as an asset register can provide asset register information to make it easier to manage and optimize state assets for the government. The asset valuation process at the Work Unit in the Denpasar High Court Area is carried out by a team of related institutions and involves a government appraiser (DJKN) or an independent (certified) KPKNL (Office of State Assets and Auction Services).

The results of this research are in line with the results of previous studies conducted by (Asman \& Akram, 2016), (Ayomi \& Suparmi, 2014), (Nasution et al., 2015), (Atikoh et al., 2017), (Hariyanto et al., 2017),
(Martini \& Midarsih, 2019), (Octanary \& Ridwan., 2018) and (Umbora et al., 2018) found that asset valuation has a significant positive effect on asset optimization. Increasing the application of asset valuation increases the optimization of assets.

\section{Influence of Utilization on Optimizing Assets}

Utilization has a positive effect of 0.04 on asset optimization and the relationship is not significant at the 0.05 level with a $t$ value of 0.35 smaller than the T-table value of 1.96 . Utilization has not been able to improve the optimization of assets, assets belonging to the state have not been utilized to the maximum. Employees at the Work Unit in the Denpasar High Court Area so far have prioritized service to the community rather than an increase in Non-Tax State Revenues. This is what causes less optimal asset management.

Utilization in the Work Unit in the Denpasar High Court Area which is happening at this time is still far from ideal. It is indicated that there are still many assets that have not been utilized by the satker, such as the example of an official house that has been published PSP (Determination of Owner Status) intended for Judges and Structural Officers but not occupied by the head of the office, on the grounds that the Judge and Structural Officer chose to occupy his own house so that the asset not occupied, even if the official residence is not occupied by the official residence can be rented to a third party and the rent becomes non-tax state income. At present the assets belonging to the Work Unit in the Denpasar High Court Area that have been utilized are only in the form of buildings that are rented out for canteens.

The results of this study contradict the results of previous studies conducted by (Ayomi \& Suparmi, 2014) and (Hariyanto et al., 2017) shows that utilization affects the optimization of assets. The better the utilization, the better the optimization of assets will be.

\section{Influence of Monitoring on Asset Optimization}

Monitoring has a positive effect of 0.17 on asset optimization and the relationship is not significant at the 0.05 level with a $t$ value of 1.41 smaller than the T-table value of 1.96. The results of this study indicate that the monitoring activities that have been carried out by the Work Unit in the Denpasar High Court Area do not have much effect on improving the optimization of assets. In general, the 
monitoring carried out by the Work Unit in the Denpasar High Court Area has been carried out properly according to the law and carried out correctly periodically (periodically) but in reality the overall monitoring activities have not been able to improve asset optimization.

Monitoring at the Work Unit in the Denpasar High Court Area which is happening at this time is still far from going well. Most users of state assets have not reported the supervision and control of assets in their satker environment to the manager in accordance with the actual conditions or circumstances. Users of state assets are still not proactively reporting the use of assets under their control, especially if they relate to the use of assets that generate state revenues.

Professionalism Human resources in managing fixed assets is also not optimal because there are still many employees who hold concurrent positions, employees from other fields who do not understand the management of assets assigned to dual positions in the field of assets, this is what causes less optimal monitoring of assets that has an impact on asset optimization.

The results of this study are in line with the results of previous studies conducted by (Asman \& Akram, 2016). (2016) shows that there is a positive and insignificant influence between monitoring and asset optimization in the Sumbawa Regency Government. The weak influence of monitoring on the optimization of assets in the Sumbawa Regency Government is indicated because the head of the SKPD is still less than optimal in monitoring the management, use or security of regional property in his control.

The results of this study contradict the results of research conducted by (Maulidiah, 2017), (Tukunang, 2016), Demetow (2017), (Tafazzoli, 2017), (Hariyanto et al., 2017), (Atikoh et al., 2017), and (Antoh, 2017) show the results that monitoring has a significant positive effect on asset optimization. If the monitoring of assets increases, the average asset optimization will increase.

\section{CONCLUSION}

Requirement planning has a positive and significant effect on asset optimization. Inventory has a positive and not significant effect on asset optimization. Identification has a positive and not significant effect on asset optimization. Legal audit has a positive and not significant effect on asset optimization. Asset valuation has a positive and significant effect on asset optimization. Utilization has a positive and not significant effect on asset optimization. Monitoring has a positive and not significant effect on asset optimization.

\section{REFERENCES}

Anartany, S. M., \& Suseno, D. A. (2018). Strategi Optimalisasi Aset Idle Daerah Provinsi Jawa Tengah. Economics Development Analysis Journal, 7(1), 32-38. Retrieved from https:// journal.unnes.ac.id/sju/index.php/edaj/ article/view/21923

Antoh, A. E. (2017). Pengaruh Manajemen Aset Dalam Optimalisasi Aset Tetap (Tanah dan Bangunan) Pemerintah Daerah (Studi di Kabupaten Paniai). Jurnal Manajemen Dan Bisnis, 1(2). Retrieved from http:// www.jurnal.manuncen.ac.id/index.php/jmb/ article/view/9

Asman, A., \& Akram, A. A. M. (2016). FaktorFaktor yang Mempengaruhi Optimalisasi Pengelolaan Aset Tetap pada Pemerintah Daerah Kabupaten Sumbawa. Assets: Jurnal Ekonomi, Manajemen, Dan Akuntansi, 6(1). Retrieved from http://journal.uinalauddin.ac.id/index.php/assets/article/ view/1598

Atikoh, N., Febrian, E., \& Hendrawan, R. (2017). Fixed Asset Management In The Indonesian Government Agencies: A Case Study At Ministry Of Trade. International Journal of Economics, Commerce and Management, 5 (12). Retrieved from http://ijecm.co.uk/wpcontent/uploads/2017/12/51240.pdf

Ayomi, E. S., \& Suparmi, C. (2014). Pengaruh Manajemen Aset Terhadap Optimalisasi Aset Tetap (Tanah Dan Bangunan) Pemerintah Daerah (Studi Di Kabupaten Manokwari) (Universitas Gadjah Mada). Retrieved from http:// etd.repository.ugm.ac.id/home/ detail pencarian/75701

Hariyanto, E. B., Wijaya, T. N., \& Handono, A. T. (2017). Strategic Assets Management: Pengaruh Manajemen Aset Terhadap Optimalisasi Pengelolaan Aset Menuju DJKN Revenue Center. BISEI: Jurnal Bisnis Dan Ekonomi Islam, 2(1). Retrieved from http://ejournal.unhasy.ac.id/index.php/bisei/ article/view/247

Hidayati, S. N. ., Wajdi, M. ., \& A.A Setyawan. (2016). Pengaruh Manajemen Aset Terhadap Optimalisasi Pemanfaatan Aset RSUD Pandan Arang Boyolali (Universitas Muhamadyah Surakarta). Retrieved from http://eprints.ums.ac.id/45599/

Ikatan Akuntansi Indonesia. 2009. Pernyataan Standar Akuntansi Keuangan (PSAK).

Jamaludin. (2017). Pengaruh Inventarisasi Aset, Legal Audit Aset, Dan Penilaian Aset Terhadap Optimalisasi Pemanfaatan Aset Tetap (Tanah Dan Bangunan) Milik 
Pemerintah Provinsi NTB. Jurnal Sekuritas Manajemen Keuangan, 1(1). Retrieved from http://openjournal.unpam.ac.id/index.php/ SKT/article/view/599

Kemenkeu. (2015). Peraturan Menteri Keuangan Nomor 166 Tahun 2015 tentang Penilaian Barang Milik Negara. Jakarta: Kementerian Keuangan.

Martini, M., \& Midarsih, M. (2019). Analysis And Optimization Of Fixed Asset Valuation Study Case In Dinas Pendapatan Pengelolaan Keuangan Dan Aset Daerah (Dppkad) Kabupaten Musi Rawas. JURNAL AKUNSTIE, 3(2), 69-81.

Maulidiah, S. (2017). Optimalisasi Pengelolaan Aset sebagai Wujud Reformasi Birokrasi di Daerah. Jurnal Kajian Pemerintahan, Politik Dan Birokrasi WEDANA, 3(1), 233247. Retrieved from https:// journal.uir.ac.id/index.php/wedana/ article/view/1811

Montayop, P. F., Ratang, W., \& Kambu, A. (2016). Faktor-faktor Yang Mempengaruhi Optimalisasi Pemanfaatan Aset Tetap. Jurnal Kajian Ekonomi Dan Keuangan Daerah, 1(2). Retrieved from https:// ejournal.uncen.ac.id/index.php/ KEUDA/article/view/733/0

Nasution, E., Nasution, H., \& Absah, Y. (2015). Pengaruh Manajemen Aset Terhadap Optimalisasi Aset Rumah Sakit Jiwa Daerah Provinsi Sumatera Utara. Reporitori Institusi Universita Sumatera Utara. Retrieved from http://repository.usu.ac.id/ handle/123456789/43647

Octanary, D., \& Ridwan., A. M. I. (2018). Analisis Manajemen Aset Pada Satuan Kerja Pemerintah Pusat di Kota Palu. E Jurnal Katalogis, 6, 30 40. Retrieved from http:// jurnal.untad.ac.id/jurnal/index.php/

Katalogis/article/ download/9894/7861

Pauweni, S., Karamoy, H., \& Gamaliel, H. (2017). Pengaruh Inventarisasi, Legal Audit, Penilaian dan Kondisi Aset terhadap Optimalisasi Pemanfaatan Aset pada Pemerintah Daerah Kabupaten Bone Bolango. Jurnal Riset Akuntansi Dan
Auditing" Goodwill", 8(2), https:// scholar.google.com/citations? user $=$ hKYHxcA.

Peraturan Menteri Dalam Negeri Nomor 17 Tahun 2007 tentang Pedoman Pengelolaan Barang Daerah

Peraturan Pemerintah Republik Indonesia Nomor 71 Tahun 2010 tentang Standar Akuntansi Pemerintahan.

Siregar, \& D, D. (2004). Manajemen Aset Strategi Penataan Konsep Pembangunan Berkelanjutan secara Nasional dalam Konteks Kepala Daerah sebagai CEO'S pada Era Gobalisasi dan Otonomi Daerah. Jakarta: Gramedia Pustaka Utama.

Sugiama, A. . (2013). Manajemen Aset Pariwisata: Pelayanan Berkwalitas agar Wisatawan Puas dan Loyal. Bandung: Guardaya Intimarta.

Sutrisno. (2004). An Investigation of Participation Project Appraisal in Developing Countries Using Elements of Value an Risk Management (Volume 1). Manchester: University of Manchester Institute.

Tafazzoli, M. (2017). Strategizing sustainable infrastructure asset management in developing countries. International Conference on Sustainable Infrastructure, 375-387.

Tukunang, S. . (2016). Manajemen Aset Daerah Pada Dinas Pendapatan Pengelolaan Keuangan Dan Aset Daerah Kabupaten Kepulauan Siau, Tagulandang, Biaro. Jurnal EMBA: Jurnal Riset Ekonomi, Manajemen, Bisnis Dan Akuntansi, 4(2). Retrieved from https:// ejournal.unsrat.ac.id/index.php/ emba/article/view/12800

Umbora, E., Falah, S., \& Pangayow, B. . (2018). Pengaruh Manajemen Aset Terhadap Optimalisasi Pemanfaatan Aset Tetap Pemerintah Daerah. Jurnal Akuntansi, Audit, Dan Aset (AAA), 1(2), 90-112. 